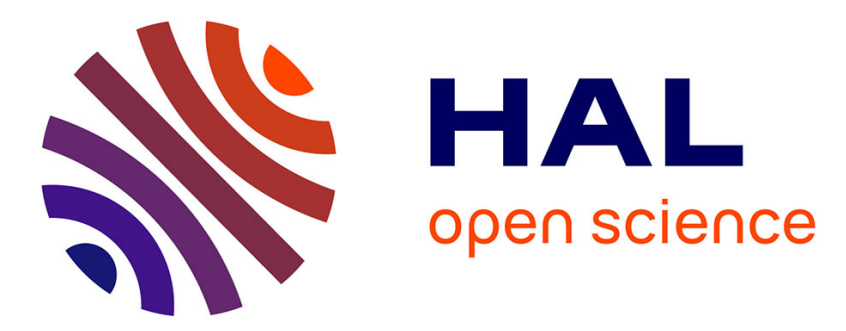

\title{
Science in contemporary British theatre: a conceptual approach
}

Liliane Campos

\section{To cite this version:}

Liliane Campos. Science in contemporary British theatre: a conceptual approach. Interdisciplinary Science Reviews, 2013, New Directions in Theatre and Science, 4 (38), 10.1179/0308018813Z.00000000060 . hal-01292795

\section{HAL Id: hal-01292795 \\ https://hal.science/hal-01292795}

Submitted on 13 Jan 2017

HAL is a multi-disciplinary open access archive for the deposit and dissemination of scientific research documents, whether they are published or not. The documents may come from teaching and research institutions in France or abroad, or from public or private research centers.
L'archive ouverte pluridisciplinaire HAL, est destinée au dépôt et à la diffusion de documents scientifiques de niveau recherche, publiés ou non, émanant des établissements d'enseignement et de recherche français ou étrangers, des laboratoires publics ou privés. 


\title{
Source for citation: Liliane Campos, "Science in contemporary British theatre: a conceptual approach", Interdisciplinary Science Reviews 38-4, December 2013, p. 295-305.
}

Copyright: $\quad$ This is the Accepted Manuscript. The copyright of the published article belongs to Interdisciplinary Science Reviews.

DOI: $10.1179 / 0308018813 Z .00000000060$

\begin{abstract}
Drawing on examples from the past twenty years of British theatre perfor- mance, a conceptual approach to the analysis of scientific ideas and discourse in dramatic and postdramatic theatre is outlined. The focus is on plays and theatre pieces inspired by the ideas, the discourse and the images of science, thereby considering it above all as a form of knowledge and enquiry (leaving aside plays that focus on the characters of great scientists, or laboratory life). Examples are all drawn from the last twenty years of British theatre, and are mostly text-based drama and performance. Three levels of analysis are proposed: discursive questions, drawing on theories of metaphor and intertextuality to examine the effects of scientific discourse on stage and the poetic uses of epistemological terminology; the relation between the embodied nature of performance and the detachment of scien- tific theory, including phenomenological descriptions of theatrical embodi- ment; and the ways in which scientific images and shapes can inspire formal experimentation in the theatre.
\end{abstract}

Keywords : science, theatre, drama, performance, metaphor, epistemology, phenomenology, formal experimentation

As interactions between science and theatre continue to develop, so too does our need for conceptual frameworks with which to analyse these trends. 'Science' in the theatre presents us with a methodological challenge, because the different meanings of this word (as a form of knowledge, an activity within a community of researchers, or a political actor in our society) andisepithe different uses to which it can be put (as a source of plots, metaphors, characters and structure) allow a great variety of approaches, from narratology and linguistics to sociological and aesthetic questions. Faced with such a multifaceted relation, I have limited the breadth of this study in two ways: first, by focusing on plays and theatre pieces inspired by the ideas, the discourse and the images of science, thereby considering it above alli great scientists, or laboratory life). Secondly, my examples are all drawn from the last twenty years of British theatre, and are mostly text-based drama and performance. This double focus allows me to propose a conceptual approach to the study of scientific language and ideas in contemporary theatre. 
I suggest three levels of analysis on which to approach this phenomenon. The first focuses on discursive questions, drawing on theories of metaphor and intertextuality to examine the effects of scientific discourse on stage and the poetic uses of epistemological terminology. The second considers the relation between the embodied nature of performance and the detachment of scientific theory. This theoretical gaze tends to be destabilized by the critical, self-questioning stance of postmodern theatre and/or the physical dynamics of performance. The resulting tensions can be analysed within the frameworks of 20th-century epistemology and philosophy of science, but also of phenomenological descriptions of theatrical embodiment. Finally, the third level examines ways in which scientific images and shapes can inspire formal experimentation in the theatre: these transfers are approached via epistemological and rhetorical conceptions of the imagination and poetics of science.

The following sections therefore suggest various analytical tools according to whether science is being used as a dramatic language, as a set of ideas to be explored in the physical environment of the stage, or as an inspiration for theatrical form. The suggested approaches complement each other, because these different uses of science generally overlap.

\section{Metaphor and intertextuality}

Science has increasingly become a source of inspiration for contemporary practitioners, yet the ideas and images that inspire them are rarely borrowed from specialized publications. Although some playwrights and directors collaborate actively with researchers, their main source of information tends to be popular science writing - the books of successful authors such as James Gleick, Oliver Sachs, or Richard Feynman. Tom Stoppard's Arcadia, for instance, is infused with the enthusiasm and sense of wonder that we find in Gleick's Chaos, and even contains the occasional sentence lifted directly from Mandelbrot's Fractal Geometry of Nature, such as Thomasina's exclamation that '[m] ountains are not pyramids and trees are not cones' (Stoppard 2009, 114). Dramatic uses of science can thus be viewed not only as a way in which ideas circulate between different areas of culture, but also as an intertextual practice.

Intertextuality, in Julia Kristeva's definition, is inspired by Bakhtin's concept of dialogism: both concepts tackle otherness in literary texts. This discursive approach allows us to investigate the textual dynamics and tensions that result from the insertion of the 'foreign language' of science into a theatre text. ${ }^{i}$ We can read the resulting plays as hypertexts reworking the hypotexts of popular science. From the point of view of the spectator, however, the effects of scientific language on stage are perhaps best analysed as an interdiscursive practice, because most members of a theatre audience are unlikely to recognize the specific popular science texts that have inspiredisepthe play, and thus to appreciate the imitations or transformations on which intertextual theory generally focuses, or the 'impossibility of living outside the infinite text' which Roland Barthes identifies as source of intertextual pleasure (Barthes 1973, 29). However, the fact that the theatre is borrowing from the discourse of science (its vocabulary and structures of enunciation) sispis immediately perceptible, and invites the spectator to judge the relation between the playtext and this discourse: is the playwright or the director aspiring to a scientific perspective? Or are they perhaps resisting it, destabilizing the language they have borrowed? The answer to these 
questions is determined by the text and performance, and also by the specific location of this scientific terminology. Placing it, for instance, in para-textual positions such as a programme, an epigraph or a company's website encourages us to look for parallels between the artistic and the scientific gazes.

When the words of science are spoken on stage, they are removed from their usual context of utterance and placed within a new frame, causing what Gillian Beer calls a 'changing of contractual terms of belief' (Beer 1990, 787). Scientific discourse can be characterized by its search for transparency and monosemy, but, as Tom Stoppard once pointed out in a lecture given at Caltech University, the exclusion of ambiguity is no longer possible in the context of the 'playful language' of theatre:

I wonder whether you think of the one-to-one correspondence of word-to-thing as a limitation to language or as a liberation from the dangers of ambiguity. [.. . I would say that purposeful ambiguity, which I suppose has no place in scientific discourse, is an essential feature of what we'll call playful language. (Stoppard 1994, 3)

The most obvious reintroduction of ambiguity occurs when scientific words are used metaphorically. When Arcadia's characters speak about 'the action isper bodies in heat', the words refer both to thermodynamics and to the sexual imbroglio at the heart of the plot (Stoppard 2009, 114). Even when a scientific term is used literally, its new context opens it up to potential connotations, analogies, and resonance with other elements of the performance.

Such ambiguities are not entirely the result of artistic manipulation. They draw on the metaphorical potential and polysemy that already characterize the language of science, and which are only contained by the context of specialized readership that defines scientific publications. According to Werner Heisenberg,

... one of the most important features of the development and analysis of modern physics is the experience that the concepts of natural language, vaguely defined as they are, seem to be more stable in the expansion of knowledge than the precise terms of scientific language, derived as an idealization from only limited groups of phenomena. (Heisenberg 1959, 171)

Words such as 'uncertainty' or 'relativity' are thus restricted by the context of scientific discourse, but reopened by their transferral to the stage. Simply because they are pronounced in a fictional context, terms such as 'chaos' in Stoppard's Arcadia or Charlotte Jones's Humble Boy are perceived by an audience first and foremost as familiar words with many possible meanings, rather than as scientific terminology with a restricted technical meaning - 'unpredictable determinism' in the case of mathematical 'chaos'. ${ }^{\text {ii }}$ Moreover, part of the appeal of science for dramatists derives from the presence of theatrical metaphors within it, as is the case in quantum physics or neuropsychology (George 1989; Baars 1997).

However, it is not always straightforward to specify a direction for the metaphorical relationship to science that we sense in so many contemporary playtexts. Is the playwright using the action as a metaphor for the science, to make it more accessible to us, or is the science providing new metaphors for the human interactions we observe? When asked to explain the conceit at the heart of his espionage thriller Hapgood, Stoppard's answer to one interviewer was that 'quantum mechanics and chaos mathematics suggested themselves as quite interesting and powerful metaphors for human behaviour' (Gussow 1995, 84), 
while he told another that the Le Carré spy-thriller world he had chosen served as 'a metaphor for physics' (Delaney 1994, 228). This ambiguity returns in Michael Frayn's Copenhagen, which both enacts the indeterminacy of quantum mechanics on stage and uses it as a metaphor for the uncertainties of history. The play uses science to make a point about history, but also uses a human narrative to explain something about physics — an anthropomorphic process which Elizabeth Leane has identified as a recurrent feature of popular physics, since their authors often rely on 'quantum fables', in other words analogies with human situations, to explain complex ideas (Leane 2007). As Kirsten Shepherd-Barr suggests, Frayn's metaphors are a performative use of scientific language, because they 'bring into being a material enactment of an abstract idea under discussion through a speech act' (Shepherd-Barr 2006, 35). Similarly, Unlimited Theatre's show Tangle used a human story of identity lost and found to explore the idea of quantum entanglement, a state in which two particles behave identically no matterispinow far apart they may be. Conversely, quantum entanglement became a structuring image for the plot: two of the main characters behaved identically at key moments of the show, although this was obvious to the audience but not to themselves. Such reciprocities can be analysed in the light of Max Black's 'interaction view' of metaphor, in which both the primary and the secondary subjects are transformed by the metaphorical relation, and we view both in a new light because we select characteristics of each that allow the analogy to function (Black 1993). Scientific metaphors, then, do not simply hijack scientific concepts to tell human stories: they are also a way of conveying them through human stories.

Spoken on stage, scientific terms are thus diverted from their usual 'technological' function (Montgomery 1996, 2) and given an ambiguous, often metaphorical part to play in the text. They play a role that is both epistemological and poetic, because they belong to scientific models but function as metaphors.

\section{Theoretical knowledge and embodied experience}

What, then, distinguishes theatrical uses of scientific concepts from similar processes that can be observed in prose fiction? Scientific language provides the theatre with heuristic metaphors, casting new light on human situations, as it does in other art forms. However, science contains a specific appeal for the theatre, because both are human activities defined by observation. The practice of borrowing ideas from scientific theories thus has not only a meta-dramatic, but a truly meta-theatrical dimension: theory, from the Greek theoria, and theatre, from the Greek theatron, are both etymologically linked to the activity of spectatorship. One of the attractions of scientific theory is its potential to redefine, by similarity or contrast, the theatrical gaze.

Two complementary frameworks can be used to tackle contemporary uses of scientific theory: on the one hand an epistemological perspective, based on philosophical approaches to postmodernism and the history of science, on the other a phenomenological perspective, grounded in an awareness of the physicality of performance. Epistemological and narrative questions are recurrent traits in the explorations of science carried out by playwrights such as Tom Stoppard (Hapgood, Arcadia), Michael Frayn (Copenhagen), Timberlake Wertenbaker (After Darwin, Galileo's Daughter), or in the collective works of companies such as Simon McBurney's Complicite (Mnemonic, A Disappearing Number) or Mick Gordon's On Theatre (On Ego, On Emotion). These plays 
generally contain at least one character that I will refer to as a theoros, who may or may not be a scientist, and who is observing and attempting to understand a human situation through rational analysis inspired by a theoretical framework. ${ }^{\text {iii }}$ In ancient Greek philosophy, the theoros appears in Plato and later in Aristotle's writings: the word, which originally means 'spectator' and refers to a traveller who goes to other cities to observes gradually becomes a model of philosophical knowledge. Aristotle thus describes the ideal philosopher as a theoros because he observes from afar, as if he were a foreigner in his own city (Nightingale 2004). In contemporary drama inspired by science, this word allows me to define category of rational, distanced characters, whose presence suggests that the theatre is a space of enquiry, and who often become figures of the spectator, channelling the audience's search for meaning. The historian Hannah Jarvis in Arcadia, the chaos-inspired character Virgil in Mnemonic, or the neurologist Alex in On Ego are all examples of this type. These theoros figures tend to be destabilized by the plot, as they find themselves drawn into the system they were observing and forced to question their certainties.

Scientific theory often provides these plays with formulations for theirsepiown uncertainties. As Niels Bohr famously declared in his assessment of the revolution brought about by quantum mechanics, 20th-century epistemology integrates the notion that researchers are no longer 'spectators', but 'actors 'isepin the theatre of life. ${ }^{\text {iv }}$ With striking consistency, scientific theory provides contemporary playwrights and directors with formulations for the instabilities they explore. The areas of science that contemporary theatre tends to favour, such as chaos mathematics, quantum physics, evolutionary theory or neurology, can all be used to highlight the limits of human knowledge - whether through the unpredictability of evolution, the sensitivity to initial conditions in chaos theory, the uncertainty principle in quantum mechanicsistop the emphasis on mystery which is often found in neurological and neuro-psychological discourse. Contemporary theatre thus favours the aspects of 20th-century science that allow it to express its own uncertainties, either metatheatrically, by questioning the possibility of neutral spectatorship, or meta-dramatically, by emphasizing the limits of linear models of causality:seppand of narrative structures inherited from Aristotle.

As a result, these areas of science allow playwrights and directors to sepiassert the fundamental instability of dramatic forms shaped by the crisis of meta-narratives and of the classic Aristotelian model. Our analysis of these affinities between postmodernist structure and borrowings from sciencessepican draw on the postmodern readings of contemporary science put forward by philosophers such as Jean-François Lyotard, Stephen Toulmin or N. Katherine Hayles. However, the question need not be reduced to whether or not these ideas are inherently postmodern. More importantly, the context of postmodernist narrative instability, which Gianni Vattimo has described as the loss of unified visions of history and a generalized fabulation and oscillation between different narratives (Vattimo 1992), helps us to understand the paradoxical appeal of these areas of science for contemporary practitioners, because they combine the confirmation of uncertainty with the possibility seper ref reintegrating it into a rational, totalizing view. Complicite's Mnemonic, for instance, is a fragmented exploration of individual and collective memories, whose shape reflects the fact that 'we no longer live in the world of the single tale' (McBurney 1999). However, the play's introductory lecture, in which the director exposes the neurochemistry of human memory, provides us with a scientific framework that gives an overarching coherence to the show. As McBurney points out, contemporary theories of memory suggest a dynamic 
relation between fragmentation and connection: 'it is not so much the cells that are important in the act of memory, but the connections between the cells, the synapses, the synaptic connections. And these connections are being made and remade. Constantly'. By placing this description in the prologue, McBurney suggests neurological fragmentation and reconnection as a model for the dynamic relation between the postmodern work of art and the spectator's gaze: 're-membering', he points out, 'is essentially not only an act of retrieval but a creative thing, it happens in the moment, it's an act, an act. . of the imagination' (Complicite 1999, 4).

Postmodernist epistemology is thus an extremely useful framework when we consider the work of artists such as Tom Stoppard or Simon McBurney, who absorb theories into their creative process and often seek out collaborations with scientists. However, these epistemological and narrative questions are insufficient when we turn to more critical explorations of science on stage, such as Caryl Churchill's dystopian vision of cloning in Number, Sarah Kane's use of psychiatric discourse in 4.48 Psychosis, Shelagh Stephenson's portrayal of medical research in An Experiment with an Air Pump, or Mick Gordon's exploration of neurological definitions of the self in $\mathrm{On} \mathrm{Ego,} \mathrm{which} \mathrm{he} \mathrm{co-authored} \mathrm{with} \mathrm{a}$ neuropsychologist, Paul Broks. In these plays, scientific descriptions are not only ways of understanding, but also a form of control exerted on the human body: in the terms of Michel Foucault, they are no longer simply a form of knowledge (connaissance), but the sign of a 'will to know' (volonté de savoir) which creates power relations (Foucault 1971). The sciences questioned by these plays tend to be biological or medical: areas of knowledge which raise questions of identity, normality and pathology, and are linked to many contemporary bio-ethical debates. These playwrights explore alternatives to the theoretical gaze of science. But the relation to science is never one of simple rejection, because they explore scientific ideas and perspectives, often integrating them poetically into their dramatic structure, while simultaneously using the theatrical medium to test their limits.

The performing body is one of the main sites of these enquiries, and its role can be analysed through phenomenology's distinctions between the body

figure 1. Simon McBurney and the cast of Mnemonic. 
as it is constructed and objectified by science, and the living body as it is experienced by the subject. Stanton B. Garner points out that this opposition can be expressed in German by the distinction between two words that both signify 'body': Körper, 'the physical body, observed from the outside and subject to biomechanical laws', and Leib, 'the body as it is subjectively lived, the experiential ground of perception, knowledge, intention, and self- extension beyond the body's physical boundaries' (Garner 1994, 109). The actor's body can thus become a site of tension between these two conceptions. In On Ego, for instance, the tension between scientific definitions of the self and the subject's experience is rendered all the more vivid by the fact that the main character, a neurologist, finds himself torn between the two. The plot is based on a thought experiment proposed by philosopher Derek Parfit around the idea of teleportation: if I am biologically scanned and replicated, and my original body is destroyed, will I have lost anything in the process? And if my original body is not destroyed will I accept to commit suicide, knowing that ' $\mathrm{I}$ ' am still living in another body? In the play, the neurologist Alex finds himself accidentally placed in precisely this situation. In an introductory lecture, using a brain in a bucket as a prop, he defends the biological view or 'bundle theory', according to which the self is nothing but an illusion resulting from neuronal activity and can therefore be replicated. However, when he himself is replicated and his original body fails to be destroyed, he refuses to commit suicide, although this would be the logical action in his conceptual framework. The rest of the play follows Alex's struggles to assert his identity, as he interacts with his wife and follows his double. Bundle theory is thus put to the test of experience, and Gordon points out that the play is structured by the tension between ' $\mathrm{a}$ biological reality as a predicate opposed to an experiential reality as a predicate'.

The corporeality of performance itself can thus be considered as a site of tension in which scientific perspectives are destabilized. These questions are relevant to conventional dramatic forms, but also to non-dramatic theatre, such as Anna Furse's Yerma's Eggs, in which Lorca's play Yerma was deconstructed and interspersed with interviews and scientific descriptions, juxtaposing medical imagery with the actors' live presence on stage. Indeed Furse employs a striking combination of discursive and corporeal terminology when describing her work: 'I am working from embodied experience. . . I aim to get under the skin of the subject matter' (Athletes of the Heart website). Scientific discourse can be put to the test of physical embodiment. It can also be destabilized from within, as in Kane's 4.48 Psychosis, in which the language of psychiatry is dispersed and de-territorialized. Although Kane's text is extremely fragmented and speakers are not identified, many of the fragments integrate medical discourse as an adversary against which the suffering subject is struggling, or as an object of parody. Medical language is appropriated by the patient and undermined by irony, particularly when the voice reads out a list of pseudo-medical notes in which the subject's anger can be heard: 'Citalopram, 20mg. Morning tremors. No other reaction. / Lofepramine and Citalopram discontinued after patient got pissed off with side affects and lack of obvious improvement. .' (Kane 2001, 224-225). In this assessment of the patient's mental and physical state, Kane destabilizes the meaning of scientific terms, by playing for example on phonetic similarities between 'side effects' and 'side affects'. She creates tensions within the language of science: in Deleuze and Guattari's terms, this appropriation can be viewed as an 'intensive' use of medical language, which multiplies internal tensions and slippages of meaning (Deleuze and Guattari 1975). Frictions between distanced and experiential points of view can thus be created from 
within language itself: in Kane's writing, the 'smooth psychiatric voice of reason' is constantly destabilized by the embodied voice of the patient.

\section{Scientific imagination and theatrical form}

For many contemporary theatre practitioners, science is not only a new language, but a stimulus for formal experimentation in drama and performance. The images and patterns encountered in science thus provide artists with new answers to the crisis of classical dramatic structures. Inis pepthe work of companies such as Stan's Cafe, Complicite, Unlimited Theatre and On Theatre, we find theatre pieces which borrow structuring images, metaphors and thought experiments from mathematics, physics and neurology, translating them into their dramaturgy and scenography. In some instances, science provides post-dramatic forms which entirely replace narrative. A minimalist example can be found in Stan's Cafe's Simple Maths, a show in which performers expressed emotions in a series of precise permutations and combinations, as they silently changed places between six chairs, encouraging the audience to 'develop their own viewing strategies... from the juxtaposition of details they are presented with' (Yarker 1997). This use of a mathematical structure to generate a theatrical situation is reminiscent of the OuLiPo's work on 'potential literature', and the various kinds of combinatorial drama imagined by their theatrical offshoot, the OuTraPo, such as Enard and Fournel's 'Theatre tree' (Enard and Fournel 1998). However, most science-inspired performances in British theatre are less categorically post-dramatic: they tend to integrate the images and forms of science into fragmented, yet still narrative-based plots.

In order to investigate these borrowings, it is useful to view science not only as the logical construction of rational thought, but as an area of imaginative activity shaped by key patterns and structures. In his studiesis pep scientific thought and imagination, Gerald Holton has suggests the term thema to define 'a dimension that can be conceived as orthogonal to the empirical and analytical content' and which plays 'a dominant role in the initiation and acceptance of certain individual scientific insights' (Holton 1973, 11). One of the themata Holton identifies in quantum physics is the idea of complementarity between different descriptions of reality: he examines the key role of this idea in Niels Bohr's research, reading, and professional relationships, long before it became a basic principle of quantum mechanics in the Copenhagen Interpretation. Viewing scientific thought through thisispillens can help us describe certain formal transfers between science and theatre that do not fall directly into the category of metaphor. Complementarity can, for example, be observed in two shows by Unlimited Theatre which were inspired by quantum physics: Neutrino, in which a pseudo-scientific lecture about particle physics provides a counterpoint to the interactions of characters whose life stories are rife with contradictions and ambiguous identities; and Tangle, in which quantum entanglement becomes an acting principle for the relation between two main characters. The characters imagined by Unlimited emphasize the existence of multiple versions of reality and of their own identities, between which they do not always choose. Complementarity thus becomes an underlying pattern, and according to Unlimited's artistic director, Jon Spooner, it informed the company's creative method: 'our interest in quantum states. . . the abstract philosophical side of quantum physics underlies everything we do about the possibility for many different versions of reality to exist'. ${ }^{\text {vi }}$ 
Formal transfers between science and theatre can also be approached by considering scientific discourse as a source of structuring schemata: key patterns which define a dramatic construction. A striking example can be found in Nick Payne's most recent play Constellations, which proposes a series of alternative interactions between a bee-keeper and a quantum physicist, Roland and Marianne. As the play gradually explores key moments of their relationship - a first date, a break-up, a chance encounter years later, a marriage proposal, the discovery that Marianne has a brain tumour different possibilities of each interaction are played out successively. Towards the beginning of the play, Marianne explains that '[i]n the quantum multiverse, every choice, every decision you've ever and never made existsisepin an unimaginably vast ensemble of parallel universes' (Payne 2012, 25).SEPTThe Many Worlds Interpretation of quantum mechanics thus provides a structuring pattern for an exploration of alternative versions of the plot. However, Payne goes beyond this familiar dramatic device by borrowing another structuring idea from science, which Marianne also points out: that of a fundamental symmetry of time in the basic laws of physics. Although the scenes initially progress forwards in time, they are interspersed by a repeated exchange between the two characters from which we first hear only the final lines, and which is gradually extended and completed each time we hear it. In this fashion the play moves simultaneously forwards and backwards in time, combining the momentum of change and death with a consoling enactment of time regained.

Payne's text illustrates how a key schema can inform the dramatic structure of a play. Moreover, schemata can also inform the scenography and dramaturgy of a show, as was the case in Complicite's A Disappearing Number, in which 'partition' (the decomposition of a whole number into a sum of other whole numbers) and 'series' were both key mathematical concepts and structuring visual principles. In the version presented at the Barbican in 2008, the stage was often partitioned by shifting, revolving screens, highlighting the many divisions between the characters and cultures represented on stage, and the actors were frequently positioned in lines that produce human 'series' at key points in the show. McBurney thus chose patterns that would underpin both the poetics of fragmentation and the search for connexions that are characteristic of Complicite's work. Such schemata are produced by the visual exploration of scientific processes and concepts, but they also can derive from the form of scientific discourse itself. As Fernand Hallyn has demonstrated, 'poetic schemata' determine the rhetoric of scientific discovery, in particular narrative structures and tropes, such as metaphor or metonymy, which shape science as a textual practice (Hallyn 2004, 12-13). Let us finally return to Complicite's Mnemonic to illustrate the generative potential of such tropes. In his introductory lecture, McBurney describes the neurological phenomenon known as 'sprouting', which creates connections between separate synapses in the human brain. Science thus provides a key schema of connective fragmentation, for a broken narrative in which we are invited to play an active part in perceiving underlying patterns and coherence. However, the metaphor of 'sprouting' is also productive in its own right. It leads McBurney to suggest another structuring image to the audience at the end of his prologue: at this point, each spectator is invited to put on a blindfold, to remove a leaf from a bag taped to their seat, to feel its veins and to imagine that they represent lines of their ancestry, in order to 'reassemble some fragments of your own'. Working backwards through the interconnected generations of human genealogy, McBurney concludes his lecture by pointing out that 'you are related to everyone sitting in this theatre' (Complicite 1999, 
6-7). The organic metaphor found in neurochemistry thus generates further organic images of connection, allowing Complicite to ground their collaborative vision of theatre in a biological paradigm of natural growth.

Science thus provides these pieces with structuring schemata, and sometimes allows contemporary practitioners to move beyond postmodern and postdramatic fragmentation, replacing linear, causal plots by other narrative logics - inspired in the examples I have given by combinatory mathematics, fractal geometry or quantum entanglement. Without reducing science to a purely aesthetic component, these formal experimentations invite us to consider its less rational aspects, as a source of images that are playing a key part in our twenty-first-century imagination.

As the field of theatre and science studies expands, new frameworks of analysis are needed if we wish to position it within the wider questions of 'science and literature' without losing the specificity of the theatrical paradigm. Tracking down this specificity has led me to propose the various questions outlined in this paper, but they should not be understood as a firm categorization of relations between science and theatre. ${ }^{\text {vii }}$ For most practitioners, science may be 'all of the above': both a rational construction and a source of poetic images, both a new dramatic language and a point of view that will be tested by the bodies of theatrical performance. Each new show will demand that we forge a new path between semiotics, epistemology, phenomenology and poetics: complementarity, once more, will be the key.

\section{References}

Athletes of the Heart website. http://www.athletesoftheheart.org. (15/12/12).

Baars, Bernard J. 1997. In the Theater of Consciousness: the Workspace of the Mind. Oxford: OUP.

Barthes, Roland. 1973. Le Plaisir du texte. Paris: Seuil.

Beer, Gillian. 1990. 'Science and Literature'. In Companion to the History of Modern Science, ed. Olby, Cantor, Christie and Hodge. London: Routledge. 783-798.

Black, Max. 1993. 'More about Metaphor'. In Metaphor and Thought, 2d ed. Ed. Andrew Ortony. Cambridge: CUP. 19-43.

Campos, Liliane. 2012. Sciences en scène dans le théâtre britannique contemporain Rennes: PUR.

Churchill, Caryl. 2002. A Number. London: Nick Hern Books.

Complicite. 2008. A Disappearing Number. London: Oberon.

Complicite, Theatre de. 1999. Mnemonic. London: Methuen.

Crohn Schmitt, Natalie. 1990. Actors and Onlookers: Theater and Twentieth-Century Scientific Views of Nature. Evanston, IL: Northwestern University Press.

Delaney, Paul, ed. 1994. Tom Stoppard in Conversation. University of Michigan Press.

Demastes William. 1998. Theatre of Chaos: Beyond Absurdism, into Orderly Disorder. Cambridge: CUP. Deleuze, Gilles and Félix Guattari. 1975. Kafka: Pour une littérature mineure. Paris: Minuit.

Enard, Jean-Pierre and Paul Fournel. 1998. 'The Theatre Tree, a Combinatory Play'. In Oulipo: a Primer of Potential Literature, ed. Warren Motte. Dalkey Archive Press.

Foucault, Michel. 1971. L'Ordre du discours. Paris: Gallimard.

Garner Stanton B. Jr. 1994. Bodied Spaces: Phenomenology and Performance in Contemporary Drama. New York: Cornell UP.

George, D. E. R. 1989. 'Quantum Theatre — Potential Theatre: A New Paradigm?' New Theatre Quarterly 5-18: 171-179.

Gleick, James. 1988. Chaos: Making a New Science. London: Penguin.

Gordon, Mick and Paul Broks. 2006. On Ego. London: Oberon.

Gussow, Mel. 1995. Conversations with Tom Stoppard. London: Nick Hern Books.

Hallyn, Fernand. 2004. Les Structures rhétoriques de la science: De Kepler à Maxwell. Paris: Seuil.

Hayles, N. Katherine. 1990. Chaos Bound: Orderly Disorder in Contemporary Literature and Science. Ithaca: Cornell UP. 
Heisenberg, Werner. 1959. Physics and Philosophy: The Revolution in Modern Science. London: Allen \& Unwin.

Holton, Gerald. 1973. Thematic Origins of Scientific Thought, Kepler to Einstein. Cambridge, Massachusetts: Harvard UP.

Jones, Charlotte. 2004. Humble Boy. Plays: 1. London: Faber \& Faber.

Kane, Sarah. 2001. 4.48 Psychosis. Complete Plays. London: Methuen.

Leane, Elizabeth. 2007. Reading Popular Physics: Disciplinary Skirmishes and Textual Strategies.

Aldershot: Ashgate.

Lyotard, Jean-François. 1979. La Condition postmoderne : Rapport sur le savoir. Paris: Minuit.

Mandelbrot, Benoit B. 1983. The Fractal Geometry of Nature. 2d ed. New York: W. H. Freeman.

McBurney, Simon. 1999. 'Collisions'. In Theatre de Complicite, Mnemonic. London: Methuen.

Montgomery, Scott L. 1996. The Scientific Voice. London: The Guilford Press.

Nightingale, Andrea Wilson. 2004. Spectacles of Truth in Classical Greek Philosophy, Theoria in its Cultural Context. Cambridge: CUP.

Payne, Nick. 2012. Constellations. London: Faber \& Faber.

Peyret, Jean-François and Alain Prochiantz. 2005. Les Variations Darwin. Paris: Odile Jacob.

States. Bert O. 1985. Great Reckonings in Little Rooms: On the Phenomenology of Theatre. Berkeley: University of California Press.

Shepherd-Barr, Kirsten. 2006. Science on Stage, From Doctor Faustus to Copenhagen. Princeton University Press.

Stephenson, Shelagh. 1998. An Experiment with an Air Pump. London: Methuen.

Stoppard, Tom. 2009. Arcadia, rev. ed. London: Faber \& Faber.

Stoppard, Tom. 1988. Hapgood. London: Faber \& Faber.

Stoppard, Tom. 1994. 'Playing with Science'. Engineering \& Science 58(1), 2-13.

Toulmin, Stephen. 1982. The Return to Cosmology: Postmodern Science and the Theology of Nature.

Berkeley: University of California Press.

Unlimited Theatre. 2002. Neutrino. DVD. Workshop Theatre, Leeds.

Unlimited Theatre. 2006. Tangle. DVD. West Yorkshire Playhouse, Leeds.

Vattimo, Gianni. 1992. The Transparent Society. John Hopkins University Press.

Wertenbaker, Timberlake. 2002. After Darwin. Plays 2. London: Methuen.

Yarker, James. 1997. 'Simple Maths'. http://www.stanscafe.co.uk/project-simple-maths.html. (15/12/12).

\footnotetext{
i French director Jean-François Peyret, who collaborates with neurobiologist Alain Prochiantz to create theatre pieces inspired by science, points out that science today often sounds like a 'foreign language' to the general public (Peyret and Prochiantz 2005, 18).

ii For an extended metaphorical use of the term 'chaos' as an approach to contemporary drama, see William Demastes's study Theatre of Chaos (Demastes 1998).

iii Stephen Toulmin uses this term to refer to the conception of the scientist as a neutral spectator, and points out that its demise in 20th-century epistemology is echoed by 'the death of the spectator' in contemporary drama such as Stoppard's (Toulmin 1982, 238).

iv Natalie Crohn Schmitt has analysed the effect of such epistemological revolutions on contemporary American theatre practices in Actors and Onlookers (Crohn Schmitt 1990).

$v$ In an interview with the author, 29/04/09.

vi In an interview with the author, 21/04/09.

vii The conceptual approach outlined in this paper is the framework I have used for a book-length study of scientific discourse in contemporary British theatre (Campos 2012).
} 